\title{
COMMUNITY COMMUNICATIONS IN ORGANIZATIONAL COMMUNICATION POLICY: Protocol aimed at territories, communities and way of life in Maranhão
}

COMUNICAÇÃO COMUNITÁRIA NA POLÍTICA DE COMUNICAÇÃO ORGANIZACIONAL: Protocolo voltado aos territórios, às comunidades aos modos de vida no Maranhão

COMUNICACIÓN COMUNITARIA EN LA POLÍTICA DE COMUNICACIÓN ORGANIZACIONAL: Protocolo dirigido a territorios, comunidades y formas de vida en Maranhão

\section{Flávia de Almeida Moura}

$\mathrm{PhD}$ in Communication from PUC-RS (Pontifical Catholic University of Rio Grande do Sul), Master in Social Sciences from UFMA (Federal University of Maranhão), professor of the Postgraduate Program in Communication - Professional Master's Degree at UFMA (Federal University of Maranhão)

flavia.moura@ufma.br, https://orcid.org/0000-0002-6672-2319

\section{Amarilis Cardoso dos Santos}

Master's Student in Communication at the Postgraduate Program in Communication Professional Master's Degree at UFMA (Federal University of Maranhão), Graduated in Public Relations at UFMA, amariliscardoso@yahoo.com.br.

https://orcid.org/0000-0002-2355-3033

Correspondence: Federal University of Maranhão, Av.dos Portugueses, s/n, Bacanga, São Luís, Maranhão

Received: 02.16.2021.

Accepted: 04.16.2021.

Published: 07.01.2021.

\begin{abstract}
The article presents part of an ongoing research that aims to understand the ways in which community communication fits into organizational communication policy. The study aims to present, as a final product, a Community Communication Protocol aimed at territories, communities and ways of life in Maranhão; a correlational method between theory and practice based on the particularities of this territory, thus becoming a possibility for the market to adopt and reapply. The main methodology used is design science (DS) as a possible path to applied research in Communication (SANTOS, 2018). The work is intended to contribute to the area of Community Communication by proposing to leave a Protocol as a contribution to the professional practice based on local reality.

$\begin{array}{lr}\text { KEYWORDS: } & \text { Organizational } \\ \text { Communication; } & \text { Community } \\ \text { Communication; Protocol. } & \end{array}$
\end{abstract}

\section{Introduction}

This article presents part of the ongoing research that seeks to understand how community communication fits into corporate organizational communication policy. The study consists of getting to know the experiences of community communication developed in three communities located in the rural area of São Luís, Maranhão. They are: Inhaúma, Coqueiro and Maruaí, and are impacted by the two largest companies in Maranhão's industry; the Maranhão Aluminum Consortium (Alumar) and Mineradora Vale, which has both investments in social programs and job creation (direct and indirect) at these locations, as well as nurturing them with environmental and social impacts. 
Below, we present the paths taken to build a Community Communication Protocol aimed at territories, communities and way of life in Maranhão; a correlational method between theory and practice based on the particularities of this territory, thus becoming a possibility for the market to adopt and reapply.

The communities chosen for this research are located in the rural area of São Luís, neighboring Alumar, as well as in the Bauxite Waste Area (ARB's) - the eight large lakes specially built for alkaline waste disposal from bauxite refinement and obtaining Alumina. The communities are also crossed by the Carajás Railroad - owned by the mining company Vale, through which the company's ore and passenger trains pass daily. The communities have characteristics of a civil society organization, through their Resident Community Associations, which have historically maintained dialogue and built relationships with both companies.

This article shows how Inhaúma, a rural community, like so many others located in municipalities in Maranhão, is directly affected and impacted by project performance and, therefore, receives attention and investments in an attempt to minimize and mitigate potential damages. It is one of the company's management policies and requirements in terms of governmental environmental conditions to permit authorization, legalization and activity control. And it is from this legal orientation that they are dedicated to searching for alternatives on how and where financial investment will be applied in order to harmonize the company interests, community needs and provide answers that meet environmental legislation.

Thus, through their Institutes, both companies allocate private social investment to be applied in social projects and programs developed in Maranhão. It is not the intention of this research to make judgments, evaluate programs, or analyze results, nor measure company reputations. Although there is already a social observation: in Maranhão, on the one hand we find extremely poor communities and on the other there are companies that invest resources in social projects (cultural, environmental, economic and humanitarian).

\section{Community Communication in organizations}

Community Communication in private organizations has become strategic and political but also a great challenge since the professional who assumes this area must always be cautious in exercising their profession: on the one hand, keeping their company's interest in mind, and on the other, respecting, listening and serving communities. Today, this group understands their place in society as subjects whose 
guaranteed rights are denied due to the absence of basic public policies or even by denying their rights as citizens.

If the change in the relational sphere between subjects and their way of living is evident, talking about the redefinition of community communication regarding the practice of integrated organizational communication is to understand and accept that we live in a society, that today, has new relationships and needs to be rethought, whether from a people perspective or from an organizational perspective. Studying old and new conceptual bases, and their links becomes necessary to understand the practices and the new meaning given to the corporate sectors and community dialogue based on the change in the world perception, from organizations to their audiences, as well as society itself with organizations.

Thus, thinking about development, the professional world, innovation, civil rights, participation, cultural production and general rights are understandings that Communication professionals should have.

In view of this new context, it is not possible to measure the degree of importance of what the market calls stakeholders; it is urgent is to identify who these groups are, and whatever the diagnosis is, communication must be prioritized. In short, the result of this research is intended to be an instrument that collaborates and strengthens Community Communication with the regionality of Maranhão, a state that possesses the worst social inequality indices in the country according to research institutes, whether in extreme poverty or in restricting access to basic rights, but which at the same time has a unique natural setting in addition to an internationally recognized popular culture, strong people, fighters and survivors, in the midst of so much social inequality.

Kunsch (2016) emphasizes that organizations live in a system of relationships, which influence and are influenced by economic, political and sociocultural means. He also says that there is no way to avoid confronting reality and social demands; that for assertive communication it is necessary to fully understand society's phenomena, the "new approaches to violence, wars, terrorism, global financial crises, social inequalities, human rights, digital literacy, multiculturalism, new skills, etc. ." (KUNSCH, 2016, p. 39).

It is noteworthy that all contributions to the area of organizational communication defended today by Margarida Kunsch result from a long trajectory of research and lived history which are recognized by this research, as well as the research and works of professor Cicilia Peruzzo (1982, 1998, 2014), a landmark and reference for Communication studies in Brazil and that transformed Community Communication in Latin America. And they are parameters followed in this research. 


\section{Integrated Organizational Communication: from theory to effective practices with communities}

With a dialectically necessary look for an initial reflection, Scroferneker (2008, p. 15) speaks of certainties and uncertainties imbued in professionals who work with Organizational Communication, in a way justifying the demands on those who work in this area, "as complex, unique and multiple subjects, the understandings of the same phenomenon, in this case Organizational Communication, will be related to our world perception, our individual and collective trajectories". After all, reality is changing, as are people, relationships, choices and certainties.

The new global scenario requires organizations in all sectors to change their way of operating, either to deal with the dynamics of new technologies or survive a versatile market which has become global with the advent and advancement of the internet.

In all diagnoses and in business planning, political and global understanding of the world has never been more present, as well as people's interaction and recognition in corporate management. Thus, concepts such as local development, sustainability, innovation, human rights, culture, popular participation and citizenship are understandings that should be part of the repertoire of professionals in this field.

Throughout history, organizational Communication has assumed an indispensable position among the alternatives of working organizational (whether public, private or third sector) survival, both from the point of view of achieving its mission and strategic objectives, or whether to build a good relationship with people, or as they're called in the market - stakeholders.

Almeida and Bertucci (2010, p. 194) sought to draw an understanding, through cataloging concepts from various authors and establishing a classification to present a relationship model to be worked on between stakeholders and a company. Thus, they systematically point out that these groups are the most relevant to be considered within stakeholders' strategic management policies: "employees, the environment, issues regarding diversity in the work environment, consumers, product safety and relationships with the community". The latter being the category that this study tries to focus on with organizational' communication policies.

Today, understanding the adoption (and need) to implement an organizational communication policy, allied to the administrative management and strategic planning models of companies is not as controversial as at other times. In this new context, it is not possible to measure the degree of stakeholder importance. What is urgent is to 
identify who these groups are, and whatever diagnosis is made, communication must be prioritized.

\section{New dimensions in Integrated Organizational Communication}

It has been some time since Kunsch (1997) presented a new paradigm for working on organizational communication; what she called "Integrated Organizational Communication"; a proposal for joining (even recognizing the specificities and differences of each sector) the synergistic actions within communication's various subareas, thus dividing: administrative, internal, institutional and marketing communication. The author proposes that these organizational communication areas be fully carried out based on the organizational mission, values and general objectives, as well as respecting and seeking to fulfill the plans, goals and specificities of each of these segments.

More recently, Kunsch (2016) suggested four new dimensions be worked on in integrated Organizational Communication: instrumental, human, cultural and strategic. According to the author, the instrumental dimension, which is directed to technical and daily tasks, based on the functional method, is still predominant in organizations. According to the author, this method still sees linear, and not systemic communication where contexts and external influence, as well as the audiences' subjective issues should be considered, seeking only to fulfill actions to be included in numbers and results in organizational balance sheets.

The human dimension, on the other hand, that which should assumably be considered primordial, by nature itself, and is not. The teacher brings numerous considerations about the reasons why it is a priority to think about people. According to her, from the moment that communication begins to be part of organizations' strategic planning, the human, relational, meaning-producing factor and vision of the historical context should be prioritized if communication is to be effective, efficient and fulfill your true intention within each organization. Far beyond the poorly prepared communication managers, this dimension is not worked on as a result of dominating and hegemonic relations of power and subordination, a capitalist legacy. And it is believed that knowing the local culture, more than subsidies instrumental tool production, should be adopted as a practice and strategic policy.

And the last dimension, the strategic one, must be rethought, according to Kunsch (2016), at each location, reality and experience. She points out that it is necessary to think of "a new management strategy" to truly implement a new strategic dimension 
for communication. And it is about this new organizational strategy that the objective is to work and collaborate in the ongoing research.

The changes in relationships did not happen overnight, stakeholder engagement regarding action planning by companies was a reflection of winning rights, where in this new situation, "civil society seems to assume its historic role of not just waiting for the State attend to their needs, but to do their part in the struggle to democratize citizenship", as stated by Peruzzo (apud KUNSCH, 2007, p. 57). The community takes on a new posture as a citizen and leader, seeking to act as a subject, especially in communication, participation and mobilization.

\section{Community Communication in the Organization Communication contexto: dialoging with communities}

Speaking of a strategic dimension in Organizational Communication is to review various practices in their areas. One of them is Community Communication. This becomes a great challenge since the professional in this area must always be cautious when working: on the one hand, the interests of their company, and on the other, respecting, listening to and serving the interests of the communities, who claim to participate in development.

In view of the Organizational Communication's restructuring trends outlined by Margarida Kunsch (2016), inspired by the participation and communication model proposed by Peruzzo (2014), as well as the experience gained from the reality of communities and social programs developed by the author of this research in the state of Maranhão, a conceptual model for managing organizational community communication is presented here as a proposal, based on concepts necessary for effective execution, which will be the basis for constructing the proposed Community Communication Protocol .

It has been pointed out that the model design illustrated in Figure 1 registers a possible representation of theoretical and conceptual elements necessary to start any work with community communication.

Figure 1 - Organizational community communication conceptual management map 


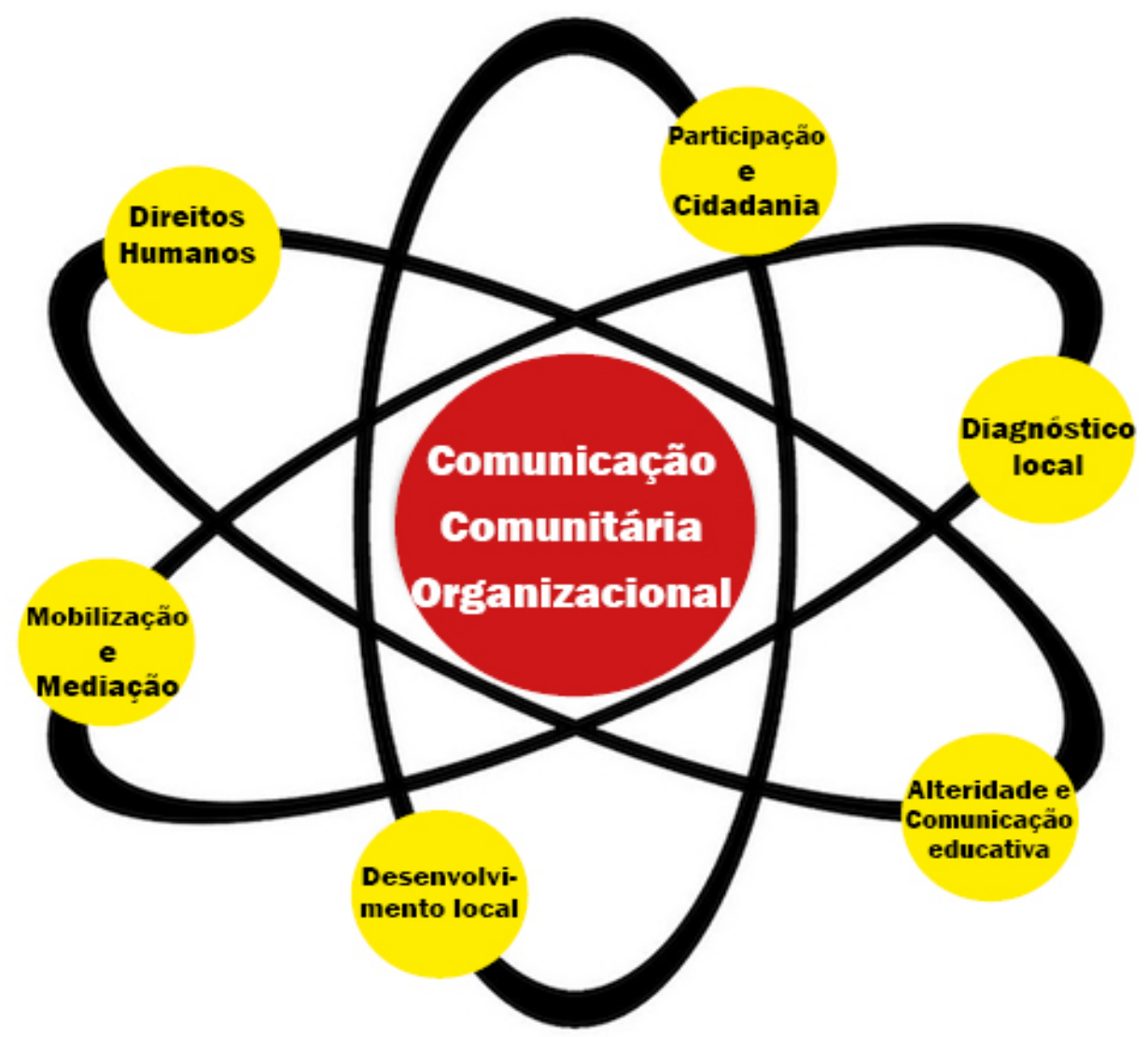

Source: The authors (2020).

Each one of these elements, which are still valid during the empirical research were based on practical lived experiences in relations between communities in Maranhão and are described as such:

- Human rights: According to Article 19 of the 1948 United Nations Declaration of Human Rights: "Everyone has the right to freedom of opinion and expression; this right includes freedom, without interference, to hold opinions and to seek, receive and transmit information and ideas by any means, regardless of borders" (UN, 1948). It is believed that it is impossible to think of a democratic society without democratic communication, and thus the pertinence of defending communication as a human right permeates. "One of the multiple instances through which man can exercise this right and this duty is with social communication" (PERUZZO, 1998, p. 275), a practical example of the application of this concept practiced by the companies Alumar and Vale in the state of Maranhão is that in both there is a community relations sector linked to 
the communication teams which seek to promote a space to dialogue and build tools for accessing information.

- Local diagnosis: it is understood that to develop any program aimed at community demands, it is essential to know the local reality, identifying where it is possible to collaborate with human, social, economic, political and environmental development, mapping all programs and projects that they are developed, either by government initiative or by nongovernmental organizations or by social movements, which usually accumulate a lot and are not always systematized in the territories. The mining company Vale, for example, prepares a Sustainability Report, whose content is focused on guidelines and commitments related to the United Nations Global Compact, the International Council on Mining and Metals and the Sustainable Development Goals (SDGs). The intention of this policy, according to the company, is to have a permanent diagnosis that presents concrete possibilities to promote sustainable development.

- Participation and citizenship: The full exercise of citizenship is participation, through freedom, creating a democratic space where it is possible to establish equality and good relationships, as well as respect for local realities. These are the reflections that Peruzzo brings to us (2014, p. 46), by its very nature, via instruments that enable the information and knowledge. Communication plays a central role in constructing citizenship. He also says that there are three types of popular participation: passive participation, controlled participation and powerparticipation, "which are not necessarily chronological nor mutually exclusive because they can be dialectically carried out " (PERUZZO, 1998, p. 78), Something that is intended to be investigated in this research is this level of participation, especially in Maranhão where poverty, lack of education and denial of rights is a reality. An example of this attempt at involvement and participation takes place at Alumar, wherein the Basic Environmental Plan presented to the Maranhão State Environment Secretariat (SEMA), referring to the authorization of the construction license for a Bauxite Waste Area (ARB), is getting ready to be "communicate" to the neighboring communities, such as the residents of Inhaúma (São Luís), about the start of the works, planning and 
implementation impacts, whether environmental or social impacts, as well as intended job vacancies for communities;

- Mobilization and mediation: It is a historically constituted practice that is legitimate and essentially political endowing individuals with freedom and autonomy to construct their relationship networks. The specific mediation scenario here is the attempt to understand how identity, knowledge and history are correlated, in addition to communication processes, taking into account that "we cannot study historical processes disconnected from the social world in which we are inserted. We cannot study communication processes without the necessary correlation between the production time and space in their relationship" (BARBOSA; RIBEIRO, 2011, p. 25). Adequate communication for social mobilization is one that assumes a dialogical, liberating and educational characteristic. In addition, understanding mobilization as a summoning of wills, in which people are called to act responsibly for the good of all, "social mobilization is a gathering of subjects who define goals and share feelings, knowledge and responsibilities to transform a given reality, moved by an agreement in relation to a certain cause regarding public interest" (HENRIQUE et al., 2007, p. 36).

- Local development: The practice of developing social programs has become a management policy for large companies around the world, whether aiming at building good community relationships or meeting the requirements of the Brazilian Environmental Legislation, or even meeting the interests of their audiences who understand their place in society. Thus, Peruzzo (apud KUNSCH, 2007, p. 51) argues that "a communication model that presupposes sustainable and participatory development is the only acceptable one in the current Brazilian situation". The intention to continue this research is to understand how these companies assume this responsibility to human life and the planet.

- Otherness and educative communication: "In communication, I welcome otherness, make room for it and experience what it can produce in me. I neither imprison nor expel it" (MARCONDES FILHO, 2018, p. 80). Understanding and experiencing otherness should be the choice of the professional who seeks to work with community communication. We are talking here about choice since it is believed that it is not technical, there 
is no manual of norms and procedures for having alterity or empathy. However, it is argued that the professional who chooses to work in community communication should, as a principle, respect others, diversity, and society's rights and values so that the educommunicative processes promote truly horizontal dialogical spaces. At Alumar, this responsibility belongs to the Institutional Relations team; and at Vale, the Community Relations team; both teams are multidisciplinary with adequate planning for diagnoses, allocated resources and defined communication actions. Our investigation seeks to understand how community communication is done based on two distinct experiences, with different subjects and interests, but based on particularities of culture and identity in the State of Maranhão.

"Popular communication contributes to citizenship and democratizing society " (PERUZZO, 1998, p. 158). Sharing the author's discourse which claims to sync with whoever recognizes communication as a human right, intends, beyond the conceptual definition, to visualize the links between these concepts and social practices, as well as applicability to Maranhão's reality and uniqueness.

\section{The history and subjects in the Rural Area of São Luís (MA)}

This research investigates three communities impacted by both Vale and Alumar, which are located in the Rural Area of São Luís (MA): Maruaí; Inhauma; and Coqueiro - located on BR 135. This article presents data from the Inhaúma community, located on BR-135, next to Alumar and divided by the Carajás Railroad, Inhaúma, according to resident Gilma Marques (verbal information):

I'm going to turn 35 years old and have lived here ever since I was a child. I moved to Estiva. I moved here, to Inhaúma, as soon as I was born. Before my father died, he me that Inhaúma was a hundred years old, and from what I understand, it out as a small dirt road, then people started showing up, clearing out the land to build houses. I don't know exactly how Inhaúma was founded, but I know it is at least a century old.

According to the information gathered, the community has 307 houses. The main sources of income are, in this order: 1) construction, at the Mateus supermarket ${ }^{1}$ and companies 2) Bolsa Família welfare benefit; 3) and retirement pensions. However, there are a large number of unemployed, especially young people.

To get familiar with the community organization in popular participation groups, a group dynamic was held, where cards with the names of community institutions were

\footnotetext{
${ }^{1}$ Main supermarket chain in the region.
} 
distributed and participant had to point out those that existed in Inhaúma and hierarchically organize who had political influence and articulation in place.

Despite all these organizations, Dona Glória, currently the main community leader, says that companies maintain a relationship with the Residents' Association which is the gateway to the community. Regarding the history of the Dona Glória Association (verbal information) ${ }^{2}$ she reveals:

The association has existed for 35 years, but was founded 34 years ago, on March 25, 1987. What I know about the association's history is from older residents such as Mr. Agenor, Mr. Libanio, Brasiliano, José Moreira and Maria Sena's family. There was no road and that's when they organized to ask a councilman to make the street. It was a struggle to create the main street which accesses the Association. People almost killed themselves over it. At that time, the Association was very involved with parties. After my tenure, I turned my attention to social projects. My term started on April 17, 2016. Why was it a party? Because there was a tradition of the Catholic Church Association organizing a Santa Luizia celebration every June. The main objective of the neighborhood association ended up being trying to get designated as a party place. It was also due to their struggle that the Association began to develop the neighborhood and schools and health posts emerged. This is the Association's history.

As in other rural communities in São Luís, Inhaúma lacks a lot of assistance and access to public policies. It was paved for the first time in 2020 , there is no health clinic, no Social Assistance Center (CRAS), there are people living in poverty, unemployment and the fear of violence (gang presence) is something recurrent in the interviewees' statements. Today, it is considered public, maintains relationships and dialogue with the companies Alumar and Vale, as well as receiving projects and benefits from social and environmental repair or volunteer actions.

In an initial conversation with journalist Déborah Maria Martins Ferreira, community relations manager at Vale, in Maranhão, actions, social projects and the communities that will receive investments (verbal information) are prioritized every year. She said that there was no social investment in the three communities that are the object in this study. In recent years they have been contemplated with income generation projects and in more structuring projects. In 2020, we worked with UBSs in this region in the fight against COVID, we donated cell phones for teleservice and PPE", among the Basic Health Units (UBSs) we covered the communities of Coqueiro and Pedrinhas, which serve people in that region.

\footnotetext{
2 Interview given by Maria da Glória Ferreira to researcher Amarilis Cardoso Santos on January 2021 in São Luís-MA (MARQUES et al., 2021).

Entrevista concedida por Maria da Glória Ferreira à pesquisadora Amarilis Cardoso Santos em janeiro de 2021 em São Luís-MA (MARQUES et al., 2021).
} 
This research aims to better understand the structuring and income generation projects that were financed by Vale in the three communities studied, as well as the legacy that remained for the communities. "It is important to always point out the challenge of carrying out actions with the community while complying with minimum standards" (verbal information) (FERREIRA, 2021), said the manager at the end of this first contact. A difficulty is evident here in the midst of the social, economic and cultural context of developing work with the communities in Maranhão, something that will be further explored with the companies in later fieldwork of this ongoing research.

\section{The case of the Inhaúma Residents' Association}

Today, it seems to be simple to believe that in the context of a society with guaranteed rights, with specific legislation aimed at monitoring social and environmental impacts, companies and organizations would dedicate more attention to assuming and repairing the problems caused by their impacts, especially those related to human beings and neighboring communities.

But, it's not that simple! It is not the practice of all organizations, although a lot has already been done. Especially because we have a more conscious and participative society, which over time has also contributed to forming a new economic and organizational model.

The great economic paradigm shifts in human history bring revolutionary communications and energy regimes, but also powerful new configurations that transform society's economic life. Each new communication/energy/transport matrix also transforms human consciousness by extending the empathic drive across broader temporal and spatial domains, thus bringing human beings together into larger symbolic families and more interdependent societies (RIFKIN, 2016, p.344).

The author records a timely reflection on today's society. There has never been so much talk about empathy, being willing to be in the other's shoes, as it is today. The author speaks of the evolution of human consciousness, even stating that "to create empathy is to civilize [...] to civilize is to create empathy" (RIFKIN, 2016, p.347), where this practical exercise in feeling the joy, sadness, fear, hope, pain, denial of rights and suffering of the other, is not just an act of solidarity with the other, but a recognition of oneself and the existence and essence of the other. What Lévinas (1980) understands in this acceptance of the other is beyond empathy, as it is not always possible to feel what the other feels, but it is always possible to recognize this other, their particular subjective issues, as well as what links this self with the other, and the broader understanding he defines as otherness: 
The way of the Self against the "other" in the world is exist, identifying yourself while in your own house. [...] Find a place and a home in the world. Inhabiting is the very way to support oneself [...]. The "at home" is not a continent, but a place where I can, where, depending on another reality, I am, despite this dependence, or thanks to it, freedeom. [...] Everything is within reach, everything belongs to me; everything is caught up in advance with the original taking of the place, everything is understood. The possibility of possessing, that is, of suspending the very otherness of what is only an "other" at first sight and in relation to me - That is the way. (LÉVINAS, 1980, p. 25).

O autor nos remete a refletir que o exercício da alteridade é também se dispor a percepção do mundo e do outro, possibilita, sobretudo, a oportunidade de (re) conhecer a si mesmo, afinal "a alteridade só é possível a partir de mim" (LÉVINAS, 1980, p. 26).

Management and business models change throughout history, but people also change. In all the analyses regarding diagnoses and strategic planning, the recognition of people, and community members in corporate management has never been so evident, as is the case with the relationship established between the community of Inhaúma and the companies Vale and Alumar, which according to Dona Glória (verbal information), the projects didn't get to the community because no one fought for them:

From 2016 until now, when I arrived, this change happened smoothly. It was a very strong struggle, coca-cola, for example, did not open its doors, but today it dialogues with the communities. Today, we have a very good relationship with the companies Vale and Alumar, but everything also depended on care and dialogue, which I think was what I needed. Because during my management in 2016 until now, relationships have changed with the communities! There's a leader who says it was because of my arrival, but in reality, it wasn't! I say it was collectivity!

Exercising citizenship, achieving rights and the possibilities of participation, through the spaces conquered, also made this audience strategic for the organizations. For example, as what happens today with Alumar and the neighboring communities according to Maria da Glória Ferreira and Gilma Marques

(verbal information) ${ }^{3}$ :

At Alumar, the problem was just a matter of job vacancies. But today, after negotiation and dialogue, this has been eased. Because today Alumar, through FIDENS, allocates job vacancies for installation and construction works for all 14 communities adjacent to Alumar and FIDENS.

\footnotetext{
${ }^{3}$ Interview given by Maria da Glória Ferreira and Gilma Marques to researcher Amarilis Cardoso Santos on January 2021 in São Luís-MA (MARQUES et al., 2021).
} 
That is why it is defended that at each location the community can be perceived based on their perception of their own otherness and that of others, recognizing the particular aspects of Maranhã's way of life, cultural characteristics, identity, identification, the local peculiarity, history, experiences and subjectivities. That companies perceive beyond repairing their social and environmental impacts, but recognize their place within that community as well.

Inhaúma (since construction of the Carajás Railroad) is cut, divided by the train line. Despite recognizing the good relationship that exists with the companies, the community is going to be impacted its whole life by that place since the company is there with them. As Sodré (2014, p. 203) points out: "the concept of community (and not just any 'communitarian' entity) tells us that "being" is to being together, being with. In other words, one does not start from the idea of an 'I' or a 'not me', but of a constitutive 'with'".

The author reinforces that this relationship might or might not be due to dialectical reciprocity, totally giving in at one moment, and totally separating at another. And these contradictions are also worth noting when trying to build the concept of community (fixed) in this new societal model that we live in, as happens in Inhaúma's reality.

Here we speak of a choice that's not believed to be technical. There is no manual of norms and procedures to build alterity or a sense of community, but it is a process of awareness and sensitization

The purpose of the Community Communication Protocol, proposed here, is to become a practical reference for constituting community communication programs that are integrated with systematized organizational communication programs which present accessible and (re)applicable tools to practice in Organizations (of any nature) based on how they perceive and look at each other's existence, and above all, on their respect for life.

\section{Methodological Trajectory}

This work is based on the qualitative research studies of Deslauriers and Kérisit (2008, p. 132), says that "beyond the methodological arguments, it seems that qualitative research is better applied to certain types of research", and presenting the arguments, described below, guides the applicability of qualitative research: a) descriptive and exploratory research: allows approximation with the studied phenomenon and because it is descriptive (in a Protocol) it serves to know the local reality, and the experiences of community communication developed by the two largest industrial companies in Maranhão (Vale and Alumar), as well as the existing barriers between people in the 
communities and companies. For this, the Sustainability and Social Balance reports will be used as a documental corpus, which are Vale and Alumar's public documents from the years 2018 to 2020. b) Study of ordinary everyday life: "The objective of qualitative research can be to deal with the concerns of public figures, as experienced in daily life" (DESLAURIERS; KÉRISIT, 2008, p. 130). To delimit three communities as the research subject, more specifically the Resident Community Associations in three communities neighborhoods in the rural area of São Luís (MA), located on BR-135 (highway to the capital): Maruaí, Inhaúma and Coqueiro. The sampling choice was made because they have particular characteristics; by violence (gang dominance, violence and criminality) present in other communities; and for having a Community Association that was willing to dialogue and intervene with the community. "Generally, when collecting information, qualitative research uses participant observation and interviews" (DESLAURIERS; KÉRISIT, 2008, p. 140). And the interview was the tool chosen for this research.

As the research that enhances the lives of social actors, not restricting them to a mere descriptive object, "one of the privileged objects of qualitative research is, therefore, in the sense that they acquire societal involvement, as well as individual involvement when it translates into collective action" (DESLAURIERS; KÉRISIT, 2008, p. 131).

The intention is to carry out empirical research in two stages: the first is the fieldwork focused on the knowledge of the subjects and later on validating the methodology and tools constructed throughout this research in order to consolidate the Community Communication Protocol.

After field experiments, systematized data and validation, it is intended to present this methodology in a creative, illustrated and accessible manner, using a design project developed especially for this final product, so that it is possible to present the proposed Protocol for this work with high user loyalty, interfacing and product interaction.

\section{Propositions to create the Protocol}

Based on the epistemological paradigm developed by Herbert Simom (1996), design science (DS) will be used to construct the research product, which Santos (2018) attests to as a possible research path applied to communication, aimed at developing solutions for responding to problems. "It is characterized by the development of research designed to confront real problems and the proposition and/or prescription of solutions, called artifacts, which represent improvements in relation to what already exists, or even completely new solutions" (SANTOS, 2018 , p. 22). 
For this production to be embodied in a document, reflections, notes and lessons learned from the theories and works of the authors researched and studied; the experience lived with the communities in Maranhão, a sample of this work will be taken into account. Among the categories and classifications of artifacts identified by design science (DS), this research will adopt methods from the perspective of Santos (2018, p. 26), revisiting March and Smith (1995), defined as: "sets of procedures and actions oriented towards the performance of a given task or solution to a given problem. The methods can be related to previously established models, being one more step on the scale between abstraction and solution tangibility". In this sense, it is proposed that the Protocol has 6 guiding axes:

1- Presentation: Telling the history! The history of the Master's program, the nature of this research, its objectives, and, finally, the trajectory and motivation to build this Protocol, as well as the importance of seeing communication as a human right and of looking at this right, from a local perspective.

2- Conceptual base: The presentation of the "Conceptual Map of Organizational Community Communication Management", inspired, above all, by the Theories of Community Communication and Participation by Cicilia Peruzzo (2014) presenting the concepts: human rights; participation and citizenship; local diagnosis; mobilization and mediation; local development; and otherness and educational communication.

3- Local diagnosis: The presentation of the "Otherness map for Community Communication", conceptual connections with otherness, which had, as references the Theory of Reception and Mediation, by Jesús MartínBarbeiro (1997), which will be built based on the study of mediation phenomena: daily family life, social temporality and cultural competence.

4- Social Articulation: A model that still has to be designed with the communities and interviews carried out with professionals who develop community communication work at Vale and Alumar. Where is it supposed to be shown: strategies for mobilization, convening, sensitization, deliberation and articulating public figures.

5- Community Communication Program: a management and organization project model, which meets the peculiarities of Maranhão, that is, it 
dialogues with the following areas: local development, human rights, culture and communication.

6- Evaluation and reapplication: presenting a model that tells the subjects involved that it is always possible to do better, that social participation and leadership is an opportunity to go from being an individual to being a subject and citizen involved in social construction.

The proposals of this study, which aims to make a contribution linked to professional practice based on regionality provide a solution and contribute to Community Communication. For this, an interdisciplinary approach is necessary, seeking to solve problems and building an experimental action protocol. Thus, after the experimental research, the study will begin carrying out applied research guidelines "used to characterize scientific initiatives aimed at solving real or practical problems" (SANTOS, 2018 , p. 20); a study applied to data collection aimed at a valid and effective solution to face a real problem.

\section{Final Considerations}

"Traditionally, qualitative research has often insisted on the personal character of the work. The researcher's involvement in their object is, therefore, emotional and would constitute the starting point" (DESLAURIERS; KÉRISIT, 2008, p. 131). As the author has expressed, this research is the result of an effective choice and the difficulties encountered, over the years, to make organizations understand the importance and how to execute (in practice) community communication based on the particularity of this territory and local communities in Maranhão. This issue is a problem that we have discussed in order to raise considerations and suggestions so that we can systematize, and finally present a potentially creative and innovative (in the local sphere) solution to our problem: a Community Communication Protocol aimed at working with territories, communities and the way of life in Maranhão.

Although not a recent concern, organizations maintain old practices, especially with regard to community communication activities, with projects designed out of context with the local reality, without reading the situation, identifying individual identities, or, in many cases, experiences innovation and empathy.

An erred understanding in thinking that actions aimed at community stakeholders do not deserve to transcend and accompany world development, technologies and, above all, of people. It is as if because of submission and poverty, the communities were content 
with the old practices of the "bread and circuses pao e circo" policy, decontextualized from the region's real social problems.

With the understanding that it is not proposing a method for popular movements, much less appropriating their history, political practice, mobilization, participation and community communication for private organizations, but rather seeking to present a model to adapt to organizational communication policies, understanding and recognizing the trajectory of popular and community communication and its legacy of constructing citizens' rights in Brazil.

Following the guidelines of the Communication and Information area document of the Coordination for the Improvement of Higher Education Personnel (CAPES) on training professionals in graduate studies, in the professional master's and doctorate modalities, this research has an interdisciplinary feel while leaving a solution and constructive legacy to society and the labor market. That's why the following is the CAPES guideline (2019, p. 16-17): "aimed at meeting social, organizational or professional demands and the labor market; producing and applying knowledge for society; adequate professional training to different types of entities". All of this, through an organizational communication tool, which hopes and believes in collaborating both with academia, the market and professionals who work with community communication in the Maranhão.

\section{References}

ALMEIDA, Ana Luísa de Casto; BERTUCCI, Janete Lara de Oliveira. Gestão estratégica de stakeholders. aspectos relevantes na definição de política de relacionamento. In:

BARBOSA, Marialva Carlos; RIBEIRO, Ana Paula Goulart. Comunicação e história. Florianópolis: Isular, 2011.

CAPES. Documento de área: comunicação e informação. Brasília: MEC, 2019. Disponível em: https://www.capes.gov.br/images/Documento_de_\%C3\%A1rea_2019/ COMUNICACAO.pdf. Acesso em: 12 jan. 2020.

DESLAURIERS, Jean-Pierre; KÉRISIT, Michele. O delineamento da pesquisa qualitativa. In: POUPART, Jean et al. A pesquisa qualitativa: enfoques epistemológicos. Rio de Janeiro: Vozes, 2008.

FERREIRA, Déborah Maria Martins. Entrevista II [jan. 2021]. Entrevistadora: Amarilis Cardoso Santos. São Luís, 2021. Entrevista por telefone.

HENRIQUE, Márcio Simeone; BRAGA, Clara Soares; SILVA, Daniela Brandão do Couto e; MAFRA, Rennan Lanna Martins. Relações públicas em projeto de mobilização social: funções e características. In: HENRIQUE, Márcio Simeone. Comunicação e estratégias de mobilização. Belo Horizonte: Autêntica, 2007.

KUNSCH, Margarida M. Krohling (org.). Relações públicas e modernidade: novos paradigmas na comunicação organizacional. São Paulo: Summus, 1997.

KUNSCH, Margarida M. Krohling. Comunicação organizacional estratégica: aportes conceituais e aplicados. São Paulo: Summus, 2016. 
LÉVINAS, Emmanuel. Totalidade e infinito. Tradução de José Pinto Ribeiro. Lisboa: Edições 70, 1980.

MARCONDES FILHO, Ciro. Comunicação ou metodologia?: a fundação de um campo da comunicação. São Paulo: Paulus, 2018.

MARQUES, Gilma; FERREIRA, Maria da Glória; FERREIRA, Inaldo; SANTOS, Maria. Entrevista I [jan. 2021]. Entrevistadora: Amarilis Cardoso Santos. São Luís, 2021. 1 arquivo mp3 (78 minutos).]

ORGANIZAÇÃO DAS NAÇÕES UNIDAS. Declaração Universal dos Direitos Humanos. 1948. Disponível em: https://www.unicef.org/brazil/declaracao-universal-dos-direitoshumanos. Acesso em: 12 dez. 2020.

PERUZZO, Cicilia Maria Krohling. Comunicação nos movimentos populares: a participação da construção da cidadania. São Paulo: Vozes, 1998.

PERUZZO, Cicilia Maria Krohling. Comunicação para o desenvolvimento, comunicação para a transformação social. In: MONTEIRO NETO, Aristides (org.). Sociedade, política e desenvolvimento. Brasília: Ipea, 2014.

PERUZZO, Cicilia Maria Krohling. Relações públicas no modo de produção capitalista. São Paulo: Summus, 1982.

RIFKIN, Jeremy. Sociedade com custo marginal zero: a internet das coisas, os bens comuns colaborativos e o eclipse do capitalismo. São Paulo: Makron Books, 2016.

SANTOS, Márcio Carneiro. Pesquisa aplicada em comunicação: o estranhamento da interdisciplinaridade que nos assombra. Comunicação \& Inovação, v.19, n. 41, v. 18-33, 2018.

SCROFERNEKER, Cleusa Maria Andrade. O diálogo possível: comunicação organizacional e paradigma da complexidade. Porto Alegre: EDIPUCRS, 2008.

SODRÉ, Muniz. A ciência do comum: notas para o método comunicacional. Petrópolis: Vozes, 2014.

\begin{abstract}
:
This text presents a critical analysis of Enem's official dissemination campaigns in the years 2019 and 2020 amidst a scenario of political tensions between government and federal universities, also marked by the coronavirus pandemic. The study shows a partial representation, in the scope of Brazilian government advertising, sciences and higher education, characterized mainly by the overvaluation of courses in Health Sciences and courses traditionally valued by the labor market, such as Law and Engineering, in contrast to the relative invisibility of Human, Social Sciences and other areas of knowledge.
\end{abstract}

KEYWORDS: Communication; Science; Higher Education; Advertising; Government Advertising.

\begin{abstract}
RESUMEN:
Este texto presenta un análisis critica de las campañas oficiales de difusión de Enem en los años 2019 y 2020 en medio de un escenario de tensiones políticas entre el gobierno y las universidades federales, también marcado por la pandemia de coronavirus. El estudio muestra una representación parcial, en el ámbito de la publicidad gubernamental brasileña, las ciencias y la educación superior, caracterizada principalmente por la sobrevaloración de los cursos en Ciencias de la Salud y cursos tradicionalmente valorados por el mercado laboral, como Derecho e Ingeniería, en contraste con la relativa invisibilidad de las ciencias humanas, sociales y otras áreas del conocimiento.
\end{abstract}


PALABRAS-CLAVES: Comunicación; Ciencias;

Educación universitaria; Publicidad;

Publicidad

gubernamental. 